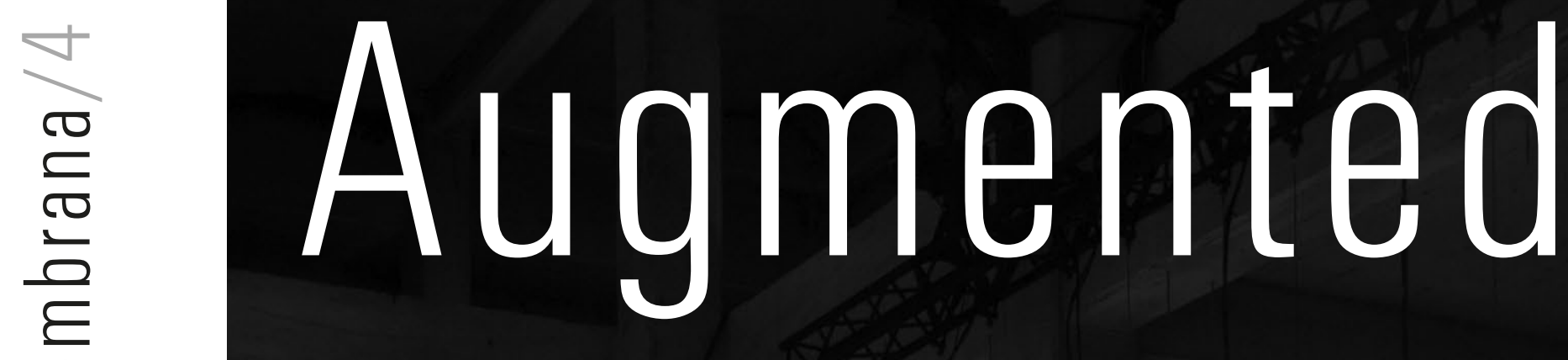

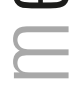
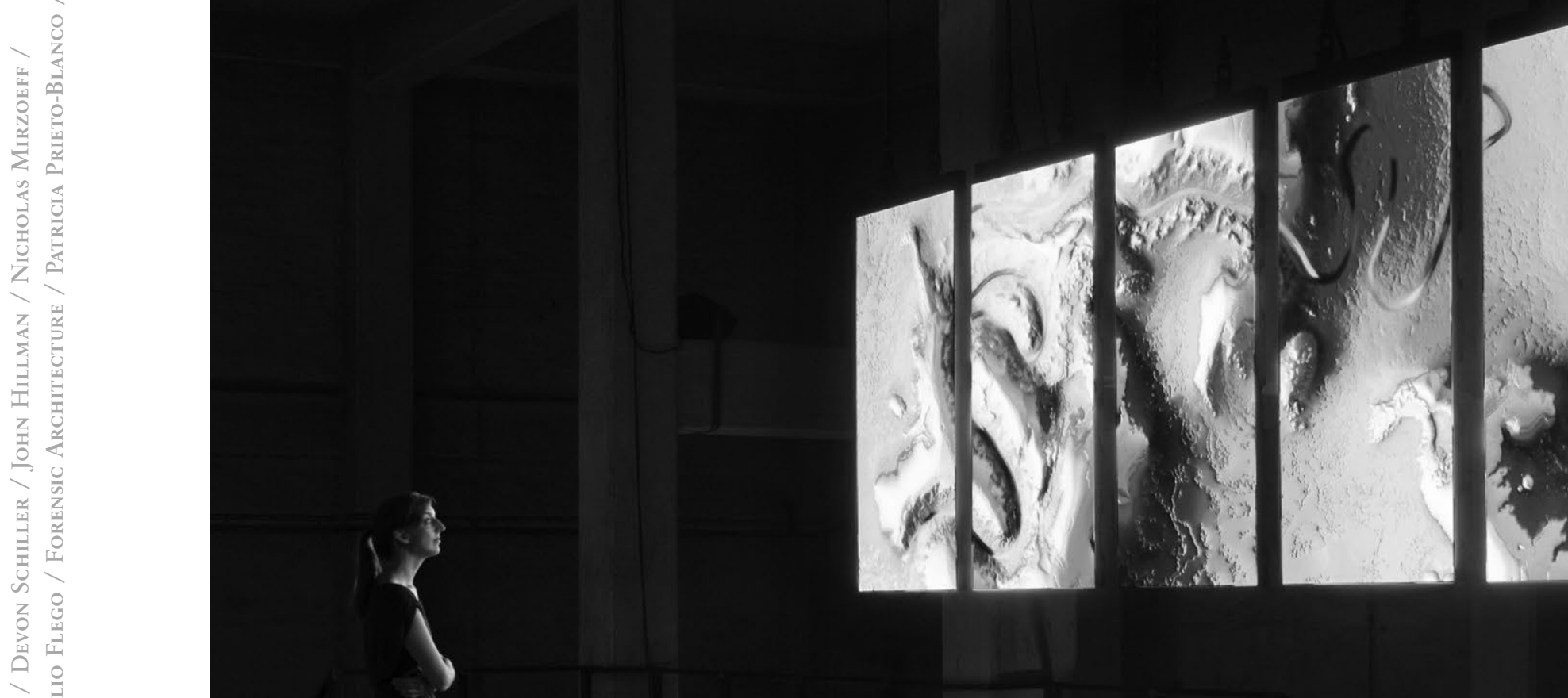
membrana/4/18

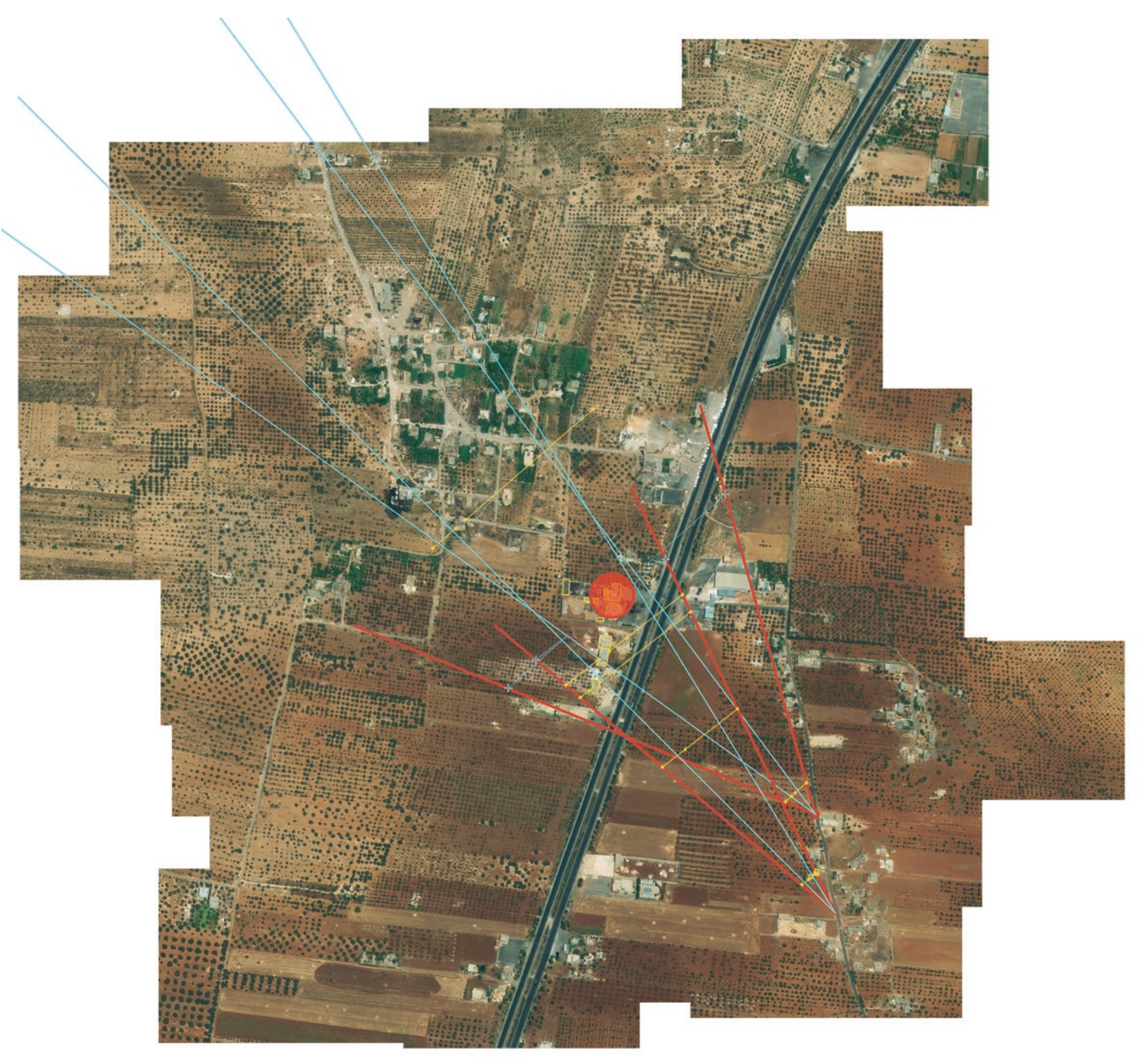

4 The Machine is Doing the Work • Interview with Nicholas Mirzoeff • Lenart J. Kučić

8 Amalia Ulman, Photographer and Artist • Miha Colner

10 Absence at the Time of Expected Authenticity $•$ Nataša Berk $•$ Miha Colner

16 Social and Pop-media as Reflection of Self • Jernej Čuček Gerbec

20 Wild Life • Anisha Baid

26 Images as Mediated Realities • Vilém Flusser and Harun Farocki in Meta-dialogue • Louise Hisayasu
Augmented
34 Reflections on Photogrammetry • Alexander W. Schindler
42 In-Game Photography • Creating New Realities through Video Game Photography • Murat Durusoy
48 Selfies and the World Behind Our Back - Ana Peraica
54 Augumenting The Physiognomic Gaze Across Space and Time •
A Conversation with onformative $\bullet$ Devon Schiller
66 The Incompleteness of Lookings $•$ John Hillman
70 Forensic Architecture • A New Photographic Language in a Factual Era • Clio Flego

76 Visual Mediations, Affordances and Social Capital • Patricia Prieto-Blanco

81 Perspective and Memory in Photographic Images • Richard Whitlock

abstracts

contributors 


\section{Visual \\ Mediations, Affordances and Social Capital}

Patricia Prieto-Blanco

"One of the more widespread suppositions about new media is that they override physical boundaries to the extreme that place does not play a role anymore."

\section{Introduction}

Digitization has given rise to a constellation of devices, platform and media usage specific to our time. This constellation, whic we may choose to call "expanded context of new media," has become commonlace for many in the last decade. Tha has familes are a good case study to in ho becte. Tanstation

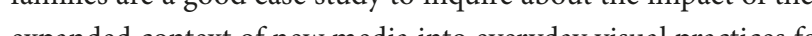
expanded cortent of new me ha into everyday vistal practices for two najor reasons. On the one hand, trans media to sustain emotional relationships (Shome 2011), whether functional or dysfunctional, affect or disaffect, visual media can be employed to transmit both. In fact, ethnographic work with IrishSpanish families living in Ireland (Prieto-Blanco, 2016), revealed that transnational families have developed tailored strategies to deal with emotional distress, frustration and uncertainty. On the other, visual mediations of space, such as the house, allow for the experience of place to be extended beyond spatial features (Rose, 2003), thus giving rise to mediated third places of socialization. Transnational families visually mediate their domestic spaces regularly. The double visual mediation of presence and space forms part of their everyday. In ethnographically exploring the ways in which transnational families employ images in the present, this research "might also account for what they think they will do in the (not distant) future" (Lanzeni et al. 2014) as well as assisting in generating wider theoretical resonance (Bourdieu et al. 1991, $\mathrm{p}$. 628) of the emerging field of visual (dis)affective media

Practice and Place

One of the more widespread suppositions about new media is that they override physical boundaries to the extreme that place does not play a role anymore. While the para-social interaction of Horton and Wohl (1956) does in fact adhere to the seeming of Hortor and wistance, place is still wholly relevat (Leeming 2011; Morley 2007). It is both a context for practice and as a product of practice. (Sarah Pink 2011, pp 93-4) In 1989 Os a coined the term third pe as the inclusively socin the infor capacity to serve the ha to their to serve he her

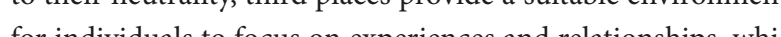
" "makes possible informal, even intimate, Helationships" to be forged anong people. (Oly among gathered individuals mentioned by Oldenburg strongly resembles the connection estabished through the openness of phatic channels observed by Malinowski. (1923) Indeed, the latter speaks about a phatic communion.

Oldenburgs key features of third places: spontaneity, congeniality playful spirit, sense of belonging and equality are mirrored by their plain architectural features (1989, pp. 21-28), or in other words, by the affordances of their interior design and location

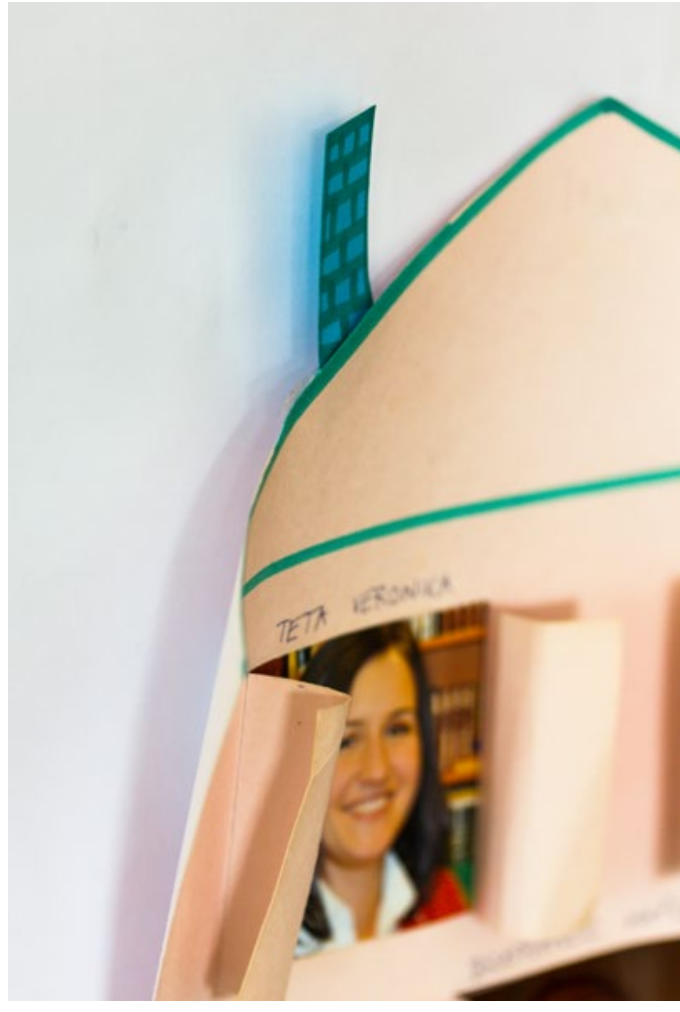

"We don't do this now very often This was more for when she was one ver old or one We to call XY:"

axample now her aunt is going to come [for a visit]. Her aunt [is coming] from Slovakia in two weeks. So by next week at the latest, we will start telling her 'You know what, vour aunte $X Y$ is coming. And even if they talk in Skype, they wont be talking that often. But

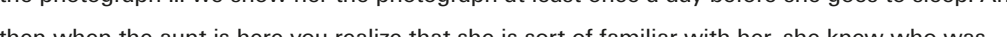
coming

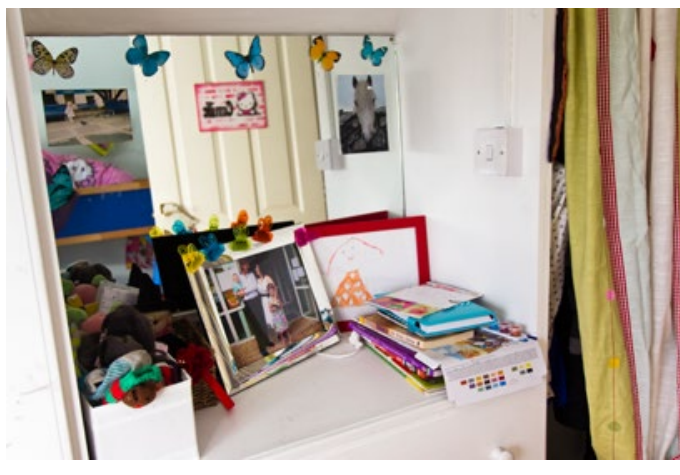

hoto disp

Celia: "If you want to see a slide-show, you are better decide to showa a photogra it needs to have a meaning. It can not be just showing for

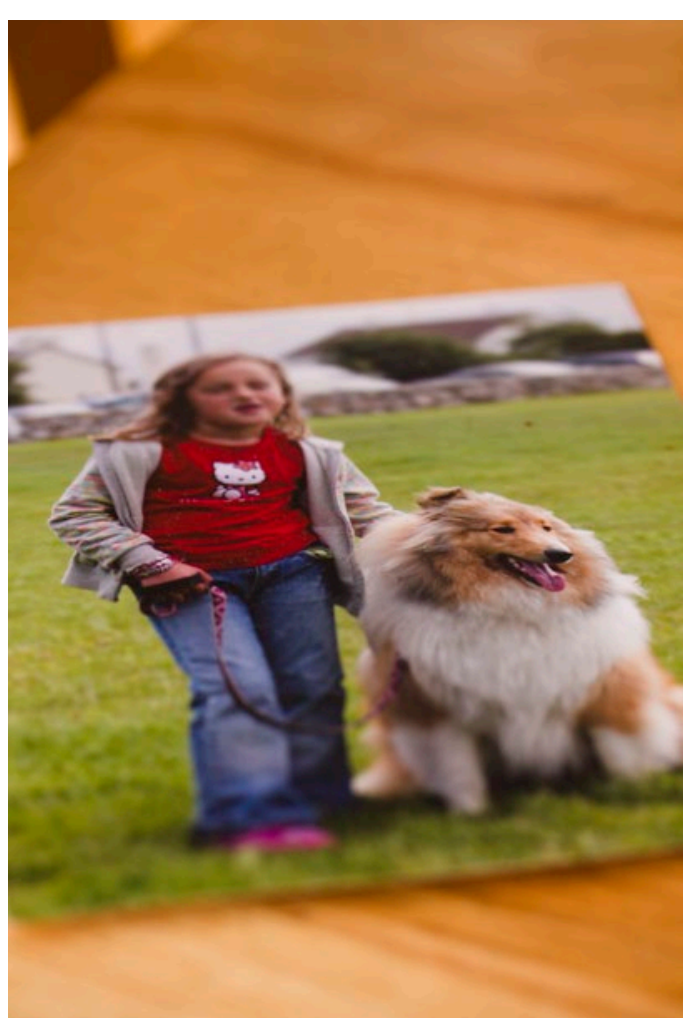

Fig. 4

Gala's dog photo. we looked through our photographs and decided to display this one [on the

Pedro: "Up until three or four months ago, we were using the digital frame. But it's a hassle.

Mika: "The screen is too small, you have to plug it in." Pedro. "But my parents turn it on every doy. They have 2000 photos in it The look at it and chat don't they Mika?" 
The popularization of mobile digital practices, those carried out via Facebook and other social networks, complement purely analogue third places by subsidizing social interactions an advancing (informal) socialization. The transfer of processes from analogue places to digital ones is more or less successful depend on the correlation between both sets of relational affordances. In examining the gradual integration of new media with the experience of place Shan Moores (2012) goes back to McLuhan's extension in order to emphasize how the medium itself, regardless of its content, impacts on everyday social interactions. Subjective and collective ag characteristics.

\section{Observations from the fieldwork}

Diasporas have always been mediated. However, while in the pas mediation has involved a time lapse, mediated presences today $c$ - and often are - instantaneous. (Ponzanesi and Leurs, 2014, p. 12) While the so called "Kodak Culture" (Chalfen, 1987) worked in the past within parameters of delays and tangibility, the very company which gave rise to it failed to meet the needs and expectations of emergent networked cultures. On the 9th of February 2012, Kodak announced that it was phasing out production of digital cameras, pocket video cameras and digital picture frames. (Zhang 2013) Accordingly, the Migration Industry of Connectivity (MIC) changed partners. First, it was Kodak; now it seems to be Skype, Facebook and other social networks who provide the technologies that fulfil the needs of families with an element of spatial dispersion.

During the 18-month fieldwork with Irish-Spanish families living in Ireland I looked at how spatial dispersion inherent to their structure was negotiated through mediated third places and the relationships thereby supported To my surprise, analos media still phy a revant part in everyday media practices of media stil pla a relevant part the ryday media practices of

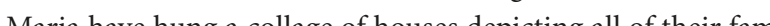

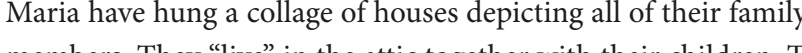
ger. They "Tive" grandparents live one floor below them and the aunts and un Eery nothe Every nigh before going to bed, Pedto and Mawias daughter says the collage (see image on $\mathrm{P} . \mathrm{XY}$ ).

Interestingly, we can see how in the example above, a sense of agency is associated with photographs. Photographs are a tool, an instrument that allows Pedros and Marias daughter to become familiar with her geographically distant relatives. As new media environments are gradually incorporated into the routines of everyday life (Miller 2010, p. 108), such as the collage of houses and the Skype calls, they are constituted into third places (Oldenburg, 1989, p. 20), which are continuous with pre-existing ones (Moore
2012, pp. 6-8). The dissemination of networked images gives rise to mediated third places. This mediated production of place is a strategy for the temporary obliteration of distance and for he enactment of ephemeral connections, or in orer words for he generation of co-presence. These digitally medist the

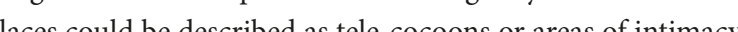
places could be described as tele-cocoons or areas of intimacy, Where relation ( development of rlatonships that had already stersed in face-to-face

Pedro: "I think that then, don't you [addressing Maria]? Well there is a time when children are afraid of strangers in general and she [Pedro's daughter] was less afraid of her family. I think that somehow, in the same way as she [Maria] was saying before that her family perceived this house as a familiar place, her family was more familiar to her [their daughter] because she had already seen them. [Maria assents]

Pedro and Marias family collage represents and constitutes a place. The extended family shapes and defines the locale (Agnew, 2011) of the home place for Maria, Pedro and their children. The collage is part of the ideal setting where everyday activities take place. Moreover, the collage itself, with its multiple photographs, enables everyday participation in place冈related affairs. Social solidarity, collective action and a sense of belonging is produced and

negotiated - partly through the collag.

Contemporary photographic practices mix analogue with digital as well as rather durable carriers, such as paper, with rather ephemeral ones, such as digital files. Underneath this variety lies the versatility of digital technologies, which have allowed Pedro's and Maria's relatives to virtually visit their new apartment in Ireland, and

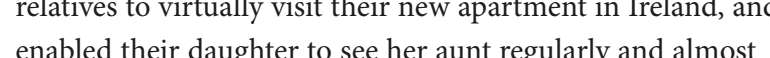
enabled their daughter to see her aunt regularly and almost in person. But as Pedro himself implied, the collage of houses fulfilled a different need. The printed photographs were a constant presence in the house. The materiality offered not only durab Pedros Pedrós and Mariás children into the larger fanily unit. Faceto-face interactions and real-time mediated ones, via Skype and similar software, take place. However, printed photographs have also p extended family in their daily lives. They literally see them every day, more than once, as they enter and leave the living room and most of the time they don't even consciously see them, but they are there. One could argue that these tangible photographs transmit a sense of ontological security because, as analogue objects, they exis in the world and hold a degree of permanence.

Digital frames seem to walk the line between the analogue and the digital. There appeared to be some value regarding how thes devices retain the formal display of paper prints, while offering some of the advantages linked to networked images. However, mos did not appreciate the sense of indecisiveness attached to digital frames. Families signalled a lack of portability, few possibilities of customization and the hassle of file transfer as hurdles and thus reasons not to incorporate digital frames into their photographic practices. Beyond that, Celia strongly believed that digital frames emptied her photographs of meaning. The stream of snapshots shown in a loop over and over again did not conform to her understanding of how and why photographs should be exhibited at home. They weren't magical enough for Celia. However, she regularly exchanged photographs through WhatsApp. For her, the difference between these two forms of exhibition was that in message applications, images are always embedded in a conversation, while that is not necessarily the case with digital frames. Pedro's parents comment on the photos as they appear on the screen of their digital photo frame; thus, embedding them in a conversation. The stream of images triggers comments. It is almost as if the photographs were taking turns in a three-way conversatio between the couple and the digital frame. With WhatsApp, there was more of a spark for Celia. She explained that when an image was shared and thus, appeared on the screen of Celia's smartphone she knew that somebody had intentionally sent it. In this way, the image still retained "the magical meaning" that Celia attributed to photographs, and the sense of permanence.

The emergence of impermanent photographs and of software too such as Snapchat indicate a different approach to photographic images. This is an approach that fosters detachment and the instrumentalization of networked images as opposed to the strong emotional attachment and "magical meaning" associated with analogue photographs. Celia certainly felt that way about photographs stored as PowerPoint presentations and digital frames. She was certain that her children disregard digital photographs easily because they are constantly surrounded by them. She though that for her children, cameras were more a toy than a tool of that for her chldren, cannas were more a toy than a tool of of photographs as memory triggers bas not been aceured (yet) by of photographs
Celia's children.

Digital and new media do allow for presence to be mediated (Villi, 2010 ) and in the process, I would argue, this intensification of $2010)$ and in the process, I would argue, this intensification of
experience is enabled through the mediation of presence and locale. However I disagree in the individualization thesis as I observed a range of social processes happening in media contexts.

Yessica: "Since we have it [Skype], my mother has had a computer for less than two months only, and we have the webcam. This is very iecent, and for her it is, well, the fac that she sends you a message are you at home, shall we go on Skype?' I don't know, obviously for her it is about seein her grandchildren live, even if they are here only for ten

minutes and then they go away. But with the computer I can
tell 'look at what this slacker is doing' and she sees that. Th webcam is very funny. Well, I hadn't used it before at all and is really like being with the person here. I mean, nothing changes. It is impressive"

Fluid third places of familial interaction are continuousl generated and continuously interrupted. Yessica almost stopped using Facebook once she was able to use Skype with her mother Celia hasn't updated her blog in over three years now but she is still very active in WhatsApp groups and one-to-one messagin Gala stopped making photo albums and printing photographs once they bought their first digital camera. Rivière links these constant dissolutions and emergences to a new understanding of collective communication, based on emotions and feelings, rathe than on rationality and information. (2005, p. 184) They foster a new form of being together. Social co-presence is enabled by these photographic exchanges embedded in continuous dialogues. However, these images seem to be forgotten as quickly as they are produced, shared and received. Pedro clearly believes this is the case: "So to speak, people look at digital photos for five minutes and they like' them but that is it, then they save them into the hard drives and they do not open the photos any more." There are two fundamental assumptions in his statement. On the one hand, Pedro expects people to save their digital photographs onto hard-drives. On the other, he thinks people do not look at offline digitally-stored photographs. Both statements were only partially corroborated in the field.

Digital images are often stored by default, be it on mobile phones, digital clouds or memory cards. Their retrieval responds to the logic of efficiency, which forces prosumers to come up with concrete storage strategies. Tagging conventions are implemented. However, looking for specific photos that have been automatically stored by any of the platforms used, such as WhatsApp or Facebook, can be very challenging. During our first meeting, Celia
showed me fairly recent photographs she had shared with her circle of references. She did so using WhatsApp on her mobile phone and perce However se did not do so and by the time I reached out to her about two wecks late she was able to find 1 ly The rest had been buried in the sea of impermanent photographs and messages that had sustained Celia’s affective and intimate relationships in spite of distances apart.

The further we move from the present, the harder it gets to find what we are looking for Bachelard (1958/1994) stated that cabinets and files substitute memory and intelligence as places of storage. However, it seems that the memory of files and folder, and the memory of family photographers speak two different languages. The former speaks of efficiency and indexing - the latter alluding to relevance and emotional meaning. When family photographers fail to bring the two together, the added memory and intelligence of folders and filing cabinets becomes an impenetrable maze that threatens to overwhelm and stress us. 
By looking at concrete examples, the potential of affordances to understand the relational properties of technologies has been highlighted. Under the lens of traditional media studies, transien and ephemerality are understood as hurdles and as intrinsic inabilities of digital media. (Ulrich, 1997; Wyss, 2000; Lunenfeld, 2002) Instead of curtailing the force of affordances before it even gets activated, a non-media centric media studies approach (Moores, 2012) allows for uncovering the potential of digital med to be both hot and cold (McLuhan, 1964, pp. 42-44). It is neither the message, nor the content, but the medium itself which has social relevance, as does its pragmatics by extension. Research discourses now heed to accontr for and reflect he (dis)arfective This paper has aimed to be a step in this direction.
Sources

Agnew, I., 2011. Space and Place. In D. Livingstone \& \&. Agnew, eds. The SAGE Handbook of Geographical Know
SAGE Publications, pp. 316-3 30.06 Poetics Today 12(4) pr627-638. Avalable at: http://ww why Chalfen, R., 1987. Snapshot Versions of Life. Bowling Green OH: The Popular Pres. Personal, Portable, Pedestrian. Mobile Phones in Japanese Life. Cambridge and

ommunication and Para - Social Interactio at a Distance. Participieations, 3(1), 2006, [online]. Avalable at: <http://www.participations.org/volume\%203/issue\%201/3_01_ hortonwohl.htm> [Accessed 15 Jun. 2016 .

.

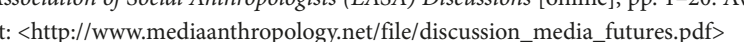
[Accessed 16 Apr. 2015].

Lapenta, F, 2011. Locative Media and the Digital Visualisation of Space, Place and

Information. Visual Studdes, $26(1)$ p. p. I-3.
unnenfeld, P., 2002. Digitale Fotografie. Das dubitative Bild * [Digital Photography fotografischen Zeitalters. Band I. Frankfurt am Main: Suhrkamp. \& I. A. Richards, eds. The Meaning of Meaning. London: Routledge and Kegan Paul LID, p. $296-336$.

dia. The Extensions of Man Critical E T

Gordon W, ed 2003 Berkeley: Gingko Prese

Miller, D., 2010. Stuff. Cambridge and Malden: Polity Press. MacMillan.

Morley, D., 2007. Media, Modernity and Technology The Geogreaty of the Nery

Constitution of Place. Visual Studies, 26(2), pp. $92-101$.

Pnzanesi, S. \& Leurs, K., 2014. On Digital Crossings in Europe. Crossings: Journal of Migration o culure, $3(1), \mathrm{pp} .3-22$.

tography, Experience and Space in Transnation Everyday Life. London: Routledge

Were, C., 2055. Mobile Camera Phones: A New Form of "Being Together" in Dally Interpersonal Communication. In R. Ling \& P. E. Pedersen, eds. Mobile
Communications. Re-negotiation of the Social Sphere. London: Springer, pp. 167-18S5 Communications. Re-negotitation of the Social Sphere. London: Springer,

Transections of the Institute of British Geographers. 28(1) pp $5-18$.

Shome, R., 2011. "Global Motherhood"; The Transnational Intimacies of White Femininity. Critical Studies in Media Communication, 28(January 2015),pp. 388-406. Wh, W., 197. Dighaler Nominalsmus. Zum Status der Computerfotografie [Digital Nominalismus. About the Status of Computer Photographyl. Fototogeschichte. Beiträge Villi, M. 2010. Visual Mobile Communication. Camera Phone Photo Messages as Ritual Communication and Mediated Presence, Helsinki: Aalto University.

Wyss, B, 2000. Das indexikalishe Bild. Hors-texte The indexical image. Horstexts.

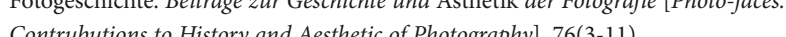

Zhang, M., 2013. Kodak to Sell Its Camera Film and Imaging Businesses in \$2.8 Billion Deal. PetaPixel [online]. Available at: Chttp://petapixel.com/2013/04/29/kodak-to-
sell-its-camera-filmXandimaging-businesses-in-28-billionXdeal $>$ [Accessed 3 Aus 20151

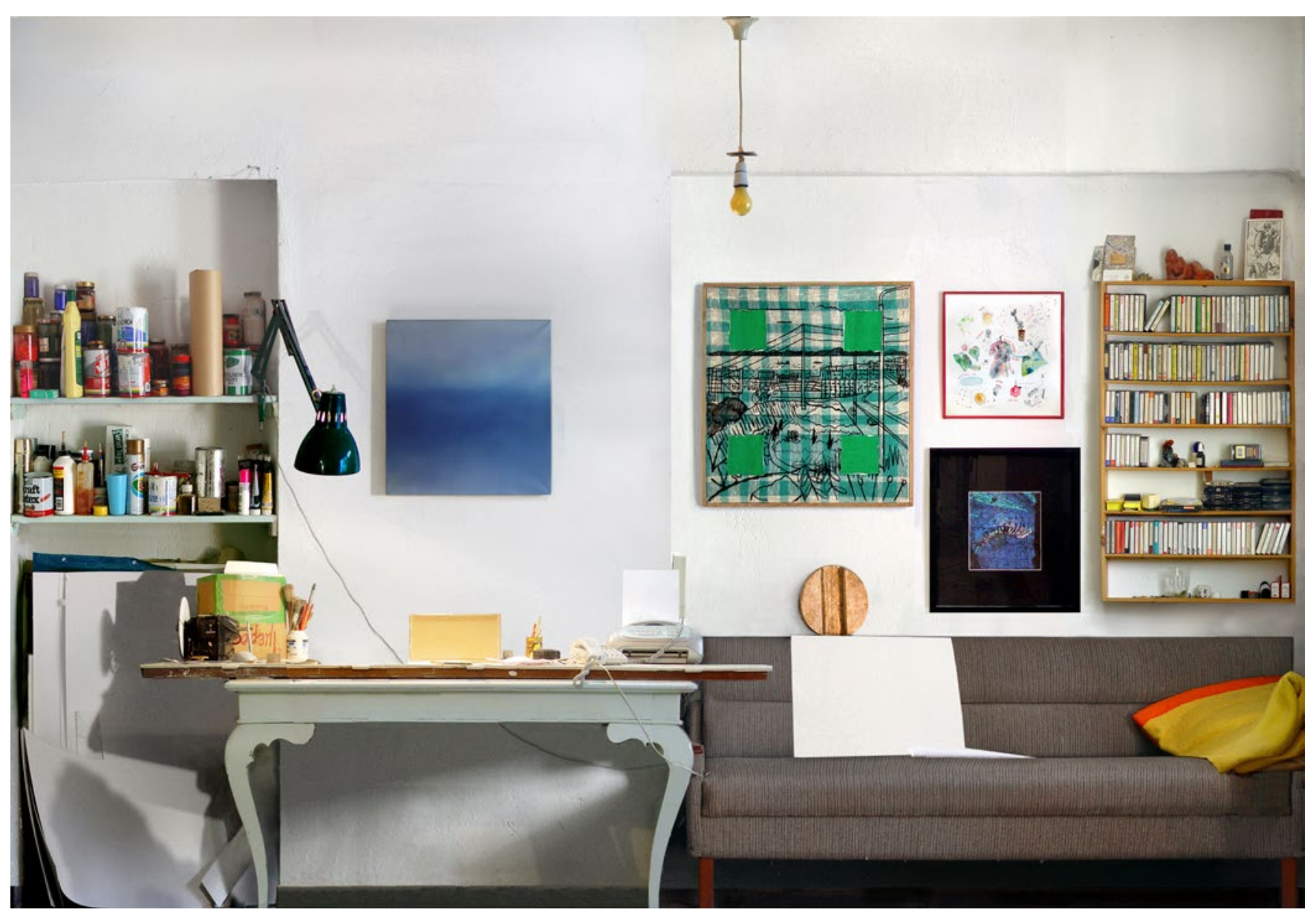

Studio Wall, 2008, inkjet print onto self-adhesive paper, $142 \times 228 \mathrm{~cm}$. private collection.

Perspective and

Memory in Photographic Images

Richard Whitlock
Digital imaging may have tied us to the computer keyboard, but it allows us to recuperate for photography the freedom and contol that painters and draughtsmen have always had when reconstructing space on a flt surface Angles of vision can be explored beyond the normal reach of the human eye or the camera lens.

For the last few years I have I have concentrated in particular on the application of orthographic projection to photographic images both moving and still. I have found that removing conventional perspective has the effect of defamiliarising and enriching what we see: objects seem to pass directly into memory not as images but as lived realities.

Still Pictures

My first "expanded view" photograph was a picture of the wall of my studio, made by combining photographs taken from many positions in space. The eye is consequently positioned in many places at once, an "augmented" eye, something like an enormous, flat lens. 


\section{Wild Life}

\section{Anisha Baid}

Wild Life is a series of augmented photographs of animals and insects placed in vacant, overgrown spaces in suburban Bangalore. Taken through mobile AR apps like Holo an Augment, these photographs (or screensho situate virtual bodies within the frame of the mobile camera - creating something in between a document and fiction. The work investigates these processes of augmentation which enable $3 \mathrm{D}$ representations of thing in the real/physical world to be projected back into physical space that are then photographed. The larger phenomenon of AR photography also complicates traditional notions of "immersive" media - forcing one to interact with their environments. This essay reflects on the implications of mobile AR photography on the image and the referent. Through a phenomenological reading of and immersion into popular uses of mobile AR (like the game Pokémon Go), the essay is an observation of the convoluted relationships evoked between augmented bodies, their environments and the screens on which the manifest.

Key Words: mobile AR, screens, documentary photography, Pokémon Go, digital image

In-Game Photography: Creating New Realities through Video Game Photography Murat Durusoy

Computers and photography has had a long and complicated relationship throughout the years. As image processing and manipulating capabilities advanced on the computer frots. photography re-birthed itself with digita cameras and digital imaging techniques. Development of interconnected social sharing networks like Instagram and Twitter feeds the photographers'/users' thirst to show off their momentaneous "been there/seen that - capt
the moment/share the moment" instincts.
One other unlikely front emerged as an image public forum. The particular role that FA processing power of the consumer electronics plays, claiming social truth and assignin to photography the function to be a "civ constructed fantasy worlds as if travelling in act, remarks its place in the history of war constructed fantasy worlds as if travelling in photography, and underlines the importan real life. While life-like graphics manufactured of also having a contra-culture in a postby the computers raise questions about authenticity and truthfulness of the image, the possible future of the photography as socially efficient visual knowledge is in constant flu This article aims to reflect on today's trend in in-game photography and tries to foresee how this emerging genre and its constructed realities will transpose the old with the new photographic data in the post-truth condition fostering for re-evaluation of photography truth-value

Keywords: Photography, Video Games, Screenshot, Digital Imaging, Lens-based

Forensic Architecture: A New Photographic Language in a Factual Er

Clio Flego

A group of visual activists, architects, softwa developers and archaeologists as well as developiculural team composed of as investigative journalists and lawyers organic orgnization. Forensic A s - an 'Investigative an. Forensic Architect agregation on do age events by the inter ever photography. Their works have been pres
in front of a court, but also exhibited at in font of a cont, but dro ex expanded use of photography, integrating in the urbanistic reconstruction of frames of any the urbanistic reconstruction of frames of kind of mithedia information collected, consider it not simply as a medium, but as a proper tool for triggering critical reflection and political action. Forensic Architecture have mainly been investigating the area of conflicts with the aim to present counterinvestigation on unclear circumstances,
often underlining social constructs in the industrial society
of technology.

Keywords: Forensic Architecture, photography, uction of event

Social and Pop-media as Reflection of Self Jernej Čuček Gerbec

The essay provides an introspection into the relationship between our identities and technology. It aims to show how our identities are affected by new modes of operation that were less accessible before the emergence of social networks. Through an observation of popular media (i.e. TV shows) and social media, it reveals how the self is convoluted, resulting into a variety of performed identities. It explores how through social media, individuals are able to create perceived identities, which are to various studies to showcase how life are interts betwen the oline bewent he onine and

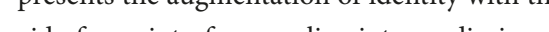
aid of new interes, onthe intenmediaries that add to he interpersonal contact, from the

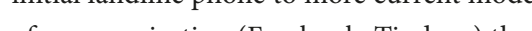
of communication (Facebook, Tinder...) the essay points out how levels of anonymity aid the emergence of new identities. It provides a mirror of contemporary life and the ways the augmented self-influences the ways understand and view our identities.

Keywords. social media, identity, performing the self, TV shows, context collapse degrees lived or completely fabricated. The essey uses Zombie and Orphn Bled. The sre intertined, resulting in the bur
The Incompleteness of Looking John Hillman

Augmented reality is fundamentally differen from virtual reality: it does not map a real world environment into a digital one as a virtual experience. Instead, it locates both reality and virtual within the same experien frame. Through it, our interactions with reality are mediated via the fantasy of an augmented experience. Thus, augmented reality supplements what we see with the purpose of trying to maintain our attention What is most fascinating about augmented reality is how reality itself becomes a part of, rather than distinct from, digital information. It is in this sense that the very notion of seeing is fundamentally challenged. Since when augmented technology is not deployed, what is left is an apparent incompleteness of simply looking. But what are the consequences of confronting this incompleteness? In this articte I examine how augmented reality simply renders a structure that has always sustained the visual field.

eywords: augmented, reality, looking, gaze, Lacan

Selfies and the World Behind Our Back Ana Peraica

pt from the upcoming book Postdigital Arcadia)

Selfie photography serves not only a tradition role of photographic (self)recording, bu also for manoeuvring the space behind ond's own back. Unfortanately, as two reallites, he unmediated and mediated, human and machine vision, are not matching, there are many accidents of selfie-makers due to the crabwalk. By this, the photographic technology based on the rear-view mirror - in which objects (may) appear closer than they are finally resolves one of the largest tragedies of human self-perception; the inability to see an control the world behind one's back.
Keywords: selfie, photography background. mobile photography, optical devices

Visual Mediations, Affordances and Social Capit Cricto-

Spatial dislocation of migrants is a catalys for early, heavy and informed media use (Ponzanesi \& Leurs 2014); as well as a motif for transnational families to form families of choice (Beck-Gernsheim 1998; Weston 1997). This text reports on how Irish-Spanis families living in Ireland manage this situatio It argues that (digital) photographic exchanges give rise to mediated third places (Oldenbur 1989), where (dis)affect and belonging are negotiated. Transnational families visually mediate their domestic spaces regularly. The double visual mediation of presence and space forms part of their everyday. This, in turn, outlines current developments in how (digit photography is used to mediate actions and emotions. In accounting for and reflecting about how (dis)affective communities of place activate affordances of media, photography emerges as a multi-dimensional site of image production, distribution and storage, in short, as a practice that is both unique to the socioough to be recognized as such across cultures and societies.

Keywords: diaspora photography visual mediation. new media, experience of place

\section{Reflections on Photogrammetry}

Alexander W. Schindler

This article presents an overview of the history, principles, and current developments in the media technological field of photogrammetry. By chronicling the isomorphic shift taking place in image capturing, we seek to show that
photogrammetry has led the way forward in seeing technical images not only as two dimensional projections, but as threedimensional model-based images. In the mid-nineteenth century, photogrammetry was first used for the documentation of architectural objects and it later became standard technique in aerial photography. Although its fields of application have become more extensive, photogrammetry's basic principle hasn't fundamentally changed: it is still defined as the threedimensional geometric reconstruction of two-dimensional photographs through the measuring of reference points. With digital technological standards and advances in camera technology, photogrammetric imaging nowadays is intensively used for object recognition in machine vision and robotics. Beside this, photogrammetry is also opening new possibilities for documentation in the fields of investigative arts, this being explored with a discussion on the "Ground

Keywords: photogrammetry, photography.

recognition

\section{Images as Mediated Realities:}

Vilém Flusser and Harun Farocki in Meta-

dialogue

Louise Hisayasu

A critical gaze and an investigative guise are necessary in a time where the uneven boundaries between "the real" and the phantasmagoric are blurred into our conceptions of reality. We are surrounded by interfaces, screens, virtual spaces and infinite networks. Technologic advancements departing from the photographic medium have the potential to change our relations to our surroundings and our conception of ourselves through images. We are no longer merely receivers of images, we are active producers of them; In the 1980's,
philosopher Vilém Flusser and filmmaker 
Harun Farocki were already engaged in questions aimed at understanding our relationship to images and our responsibility towards the production images. Both urged their readers and spectators to engage in dialogue, to understand the phenomenon of photography and its direct correlations mass communication structures.

Keywords: responsibility, technical images, reality codes, communication the

\section{Machine is Doing the Work:}

Interview with Nicholas Mirzoef

Lenart J. Kučic

Prevedla Anja Kos

Optical and mechanical tools were the first major "augmentation" of human senses.

The microscope approached the worlds that

were too small for the optical performance of the eye. The telescope touched the too

far-off space; X-rays radiated the inaccessible interior of the body. Such augmentations were not innocent, as they demanded a differen interpretation of the world, which would correspond to images of infinitely smal is now happening with cloud computing machine vision and artificil intelliting, these tools, it may be possible to compere the by people and mochines. But who will analyze by people and nachines. But who will analye hese us ages and for what purpose? Wit they hep us to beter un hijacked by attention-merchants and political demagogues who are effectively spreading demagogues who are effectively spreading technologies?

Keywords: augmented photography, reality, machine learning ran

(n)

Augumenting The Physiognomic Gaze Across Space and Time:

Augmented photography can be used in the digital arts to over-code upon real-world environments with computer-generated data in order to translate stimuli across sensory modalities, and thereby extent or increase our faculties for perceiving spatial and temporal relations. Because of this mediaspecific affordance, the augmentation of the photographic medium may have especia application for the "physiognomic gaze," a way of doing "form interpretation" or "natur knowing" based on the physical behaviors and psychological phenomena of the human face, head and body. The innovativeness of such technological prosthetics becomes manifest how new ways are generated to both perceive and to know those experiences that were previously unseeable or otherwise unsensable. Here, I converse with Cedric Kiefer (co-founder and creative lead) of the onformative studio for digital art and design in Germany about their works Meandering River (2017), Pathfinder (2014) and Google Faces (2013). And we explore bow onformative uses the augmented photograph in their digital artworks to extend the physiogno gaze bringing dat not visble to the note into the senseable sphere to offer different perspectives about space and time.

Keywords: onformative, augmented photography, physiognomic gaze, digital art, computegenerated data

\section{Perspective and Memory in Photographic} Images

Whitlock

Digital imaging may have tied us to the computer keyboard, but it allows us to recuperate for photography the freedom and control that painters and draughtsmen have always had when reconstructing space on a flat surface. Angles of vision can be explored beyond the normal reach of the human eye or the camera lens. For the last few years I have concentrated in particular on the application of orthographic projection to photographic images, both moving and still. I have found that removing the conventional perspective has the effect of defamiliarising and enriching what we see: objects seem to pass directly in memory not as images but as realities.

\section{Keywords. mown}

de-perspective, expanded view, photography

(n)

Raid is an artist and writer based in Bangalore. India Her practice and research involve an investigation of pervasive technologies through an examination of their design, diversity of use, and their relationship with ideas from science fiction. Most recently she has been researching the phenomenon of Text-to-Speech and machine generated voice. She is currenty a student of Experimenta Media Art at Stishti School of Art, Desig , and Technology (Bangalore, India).

Murat Durusoy (1985) is a photographer, Turkey. He is currently pursuing a $\mathrm{PhD}$ in Media and Communications. His work can be found on www.muratdurusoy.com and @ mdurusoy on social networks.

Clio Flego (1987) is a researcher, manage, video maker and activist. She studied at IUAV University in Venice and received a graduate degree in Visual and Performing Arts. Clio has collaborated with internationa festivals and events such as, among others, 7th International Histories of Media others, 7 International Histories of Media Art, Science and Technology Conference in Austria (2017) Madeira Film Festival (2015, 2016), and L (2014). As a creative and critic he (2014). As a creat we es cical hinker, cul in clu ind Roma Trial, MACBA
Venice Biennale.

Jernej Čuček Gerbec is a media agnostic artist with an interest in theory and visual culture. His work has been shown in Sloven Finland and USA. His artistic practice is not concerned with medium or concept but with observations. Observations of the comm conventional and the widespread. The artist finds poetics in the simple acts of life, recurring conversations, pictures of random passers-by and quotidian struggles. The end result is never a simple act of documentation, but varies between installation, photography, video, text and sculpture. In his work, he tries to highlight the things that may go unnoticed, while at the same time making the end message ambiguous and unclear to retain its former allure. He earned his MA in Visual Culture and Contemporary Art at Aat University and a BA in Photography at VIST.

John Hillman is an educator, imasemaker, researcher and writer engaged in the interdisciplinary areas of photography. image and visual culture. He currently works as Course Director of the Department of Photography at Birmingham City University. His interests lie in philosophical approaches to contemporary culture and understanding how images and media technologies shape our experience. What unifies all his interests is the exploration of how theory can enrich and offer new insights to creative practice and lived experience.

Dr. Ana Peraica is the author of Fotografija

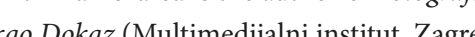
2018). Culture of the Selfie (Institute of Network Cultures, Amsterdam, 2017) and versions (Revolver Berin 2009) She is S the editor of Smuggling Anthologies (MMSU, Rijeka, 2015), Victims Symptom (Institute Rijeka, 2015), Vclims Symptom (Institute or Network Cultures, Amsterdam, 2009), Splt 2007). Her chap Split, 2007). Her chapters are on anthologies published by Afteral/MIn Press, Loecker Verlaag, Samarah Institute of Cultural Studis and others. She is the author of entries in encyclopaedia editions published by Sage. Her articles were published by scholarly journals like Leonardo, Afterimage, as well as magazines such as Springerin, Flash Art Fotografija and many others. She is curren working on the book Postdigital Arcadia and coedits Intelligent Agent Reader with
Patrick Lichty She teaches at MA Media Art
Histories program at the University of Danube in Krems, as well as at the MA Media Art Cultures (ERASMUS MUNDUS) program a the University of Danube, Aalborg, Poznan and Singapore. Peraica lives and works in Diocletian's palace, in Split (Croatia), where she runs a family photo shop Atelier Perajica and actively engages in the preservation of life inside this nhabited Roman monument on the

Dr. Patricia Prieto-Blanco is a Senior Lecturer at School of Media, University of Brighton. However, she prefers to be defined as a critical thinker and visual maker. Her research interests are: photography, methods and methodologies, mediation of the everyday and migration. Patricia advocates interdisciplinary, practice-based and collaborative research. In her spare time, she tries to subvert neo-liberal, capitalist, patriarchal norms via http://www. hystericalfeminisms.com/.

Alexander W. Schindler has a master's degree in Communication and Media from the Berlin University of the Arts. He also worked for the university’s Vilém Flusser Archive. Hailing from a background as a reseach now revolves aund medis thery escar me ploger hotographic era.

Louise Hisayasu is pursuing her postgradu studies in the field of digital humanities. She spent some months interning and conducting researching at the Vilém Flusser Archive in Berlin. She is currently based at the School of Creative Media at City University of Hong Kong 
Nicholas Mirzoeff is professor of media, cultural and communication studies at the American University of New York Steinhar He described the field of visual culture two overview books: An Introduction to Visu Culture (1999) and The Visual Culture Reader (1998). He later devoted himself to the phenomenon of modern visual communications. In the book How to See The World (2015), he described the effects of the first visual revoluton of the 19 h centry (the emergence of flim, photography and $\mathrm{X}$-rays) and scientific inventions of the $17 \mathrm{t}$ century (microscope, telescope, and maps) and put them in the context of the present visual abundance of Facebook, Instagram and images of surveillance cameras. With the book The Right to Look: A Counterhistor of Visuality (2011), he explored alternative visual (political) history of the 20th century including the Black Lives Matter movement which he covered as a visual activist.

Lenart J. Kučic is a journalist, lecturer and researcher of mass media. For 10 years, he covered the intersection of media, technolo and society for Delo newspaper Saturday supplement. Last year he joined the media for investigative journalism Pod črto (The Bottom Line). He is also the founder of the Marsowci podcasting network and co-auth of several research and expert articles on media ownership.

Cedric Kiefer is co-founder and creative lead

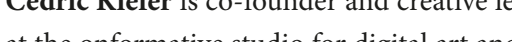
design in Bering Gernany He estibs the Studio in 2010 a ta restored factory alo the Studio in 2010 a a restored fatory, along with co founder and managing director Jalia designers, onformative exhibits their work in Australia, China, Europe, and North America as well as having clients such as Nike and as well as having clients such as Nike and
Porsche. In 2013, the Art Directors Club Porsche. In 2013, the Art Directors Club
(ADC) recognized Cedric as a "Young Gun" for his vanguard creativity.

Devon Schiller is a media rhetorician an visual semiotician in the Department of Ing Science at Danube University, Austria. His scholarship centers on studies of the face done the intersection between art, science and Devon is certificate trained in the Facial Action Coding System (FACS), as well as the Neuropsychological Gesture Coding System (NEUROGES), and has conducted grant-supported research on automated faci Interiste for

Richard Whitlock is an artist, sculptor an film-maker. He has made sculptural, graphic and photographic installations in Mosco Beijing, New York, Helsinki, Marseilles, Athens and elsewhere. In 1997, he exhibited in Ljubljana, and drew the view from the window of a cell in Metelkova prison on the wall in the cell. His non-perspectival photographs and "moving pictures" are discussed in Joanna Zylinska’s Non-human photography (MIT Press, 2017), in Afferimage and in Photomediations Machine. He has written and lectured widely on the question of perspective in photography, and is currently writing about "anti-perspective" in Byzantine and Chinese art for a book to be published by the Centra Academy of Fine Arts in Beijing. He lives in Greece.

Wwwrichardwhitlock..gr; https://vimeo.com/ whitlock

whitlock@otenet.gr

Nataša Berk graduated from the Academy of Fine Arts in Vienna, and since 2003 he regularly crestes and presents multim interdiciplina wo ranging from paform ing res drewings to vist pons, photographs, videos, drawngs to vistal poetry.

Amalia Ulman (1989) is a visual artist born Argentina. In 2011 she graduated from the Central Saint Martins College in London. In hers author's practice she addresses phenomena such as class struggle, social gender, representation of individual in mas media and on social networks, while using photos, videos, performative practices and modern communication tools, which often go beyond classical gallery practices. Ulman lives and works in Los Angeles.

Miha Colner (1978) is an art historian who works as a curator and programme coordinator at the International Centre of Graphic Arts / Svicarija Creative Centre in Ljubljana. He is also active as a publicist, specialised in photography, printmaking, artists' moving image and various forms of (new) media art. In the period 2006-2016 he was a curator at Photon - Centre for Contemporary Photography, Ljubljana. Since 2005 he has been a contributor of newspapers, magazines, specialist publications, and his personal blog, as well as part-time lecturer. He lives and works in Ljubljana, Slovenia. http://mihacolner.com http://www.mglc-lj.si

\section{BOOKSTORE AND GALLERY FOTOGRAFIJA}

Photographic literature, overviews,

photobooks, magazines, exhibition catalogues ...

Levstikov trg 7, Ljubljana, Slovenia

www.galerijafotografija.si

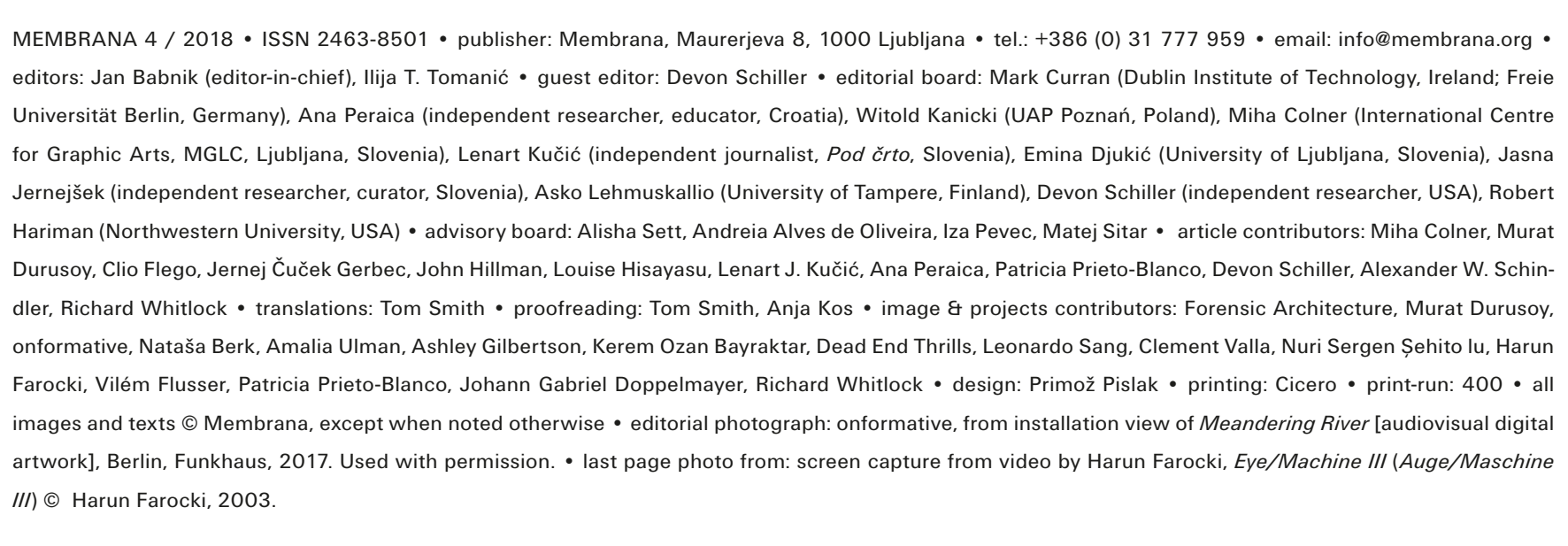




\section{Awww.membrana.si $=2\}$}

$$
=-\quad \text { - }
$$

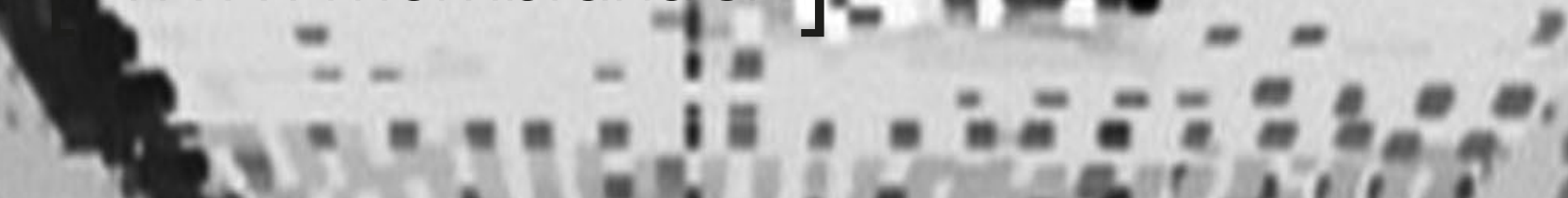
की

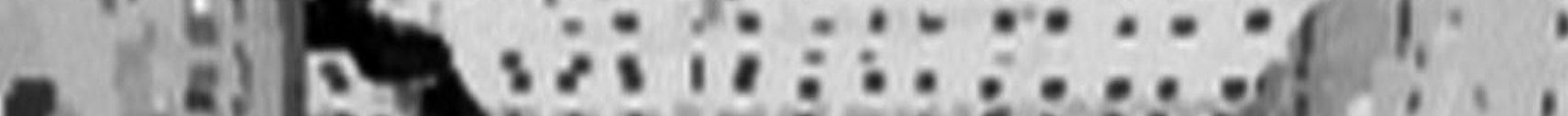

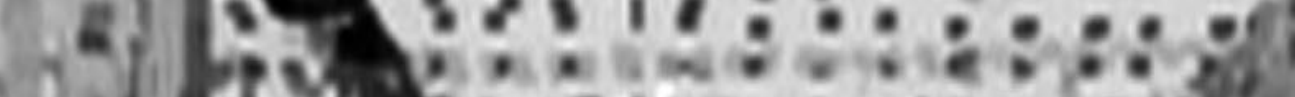

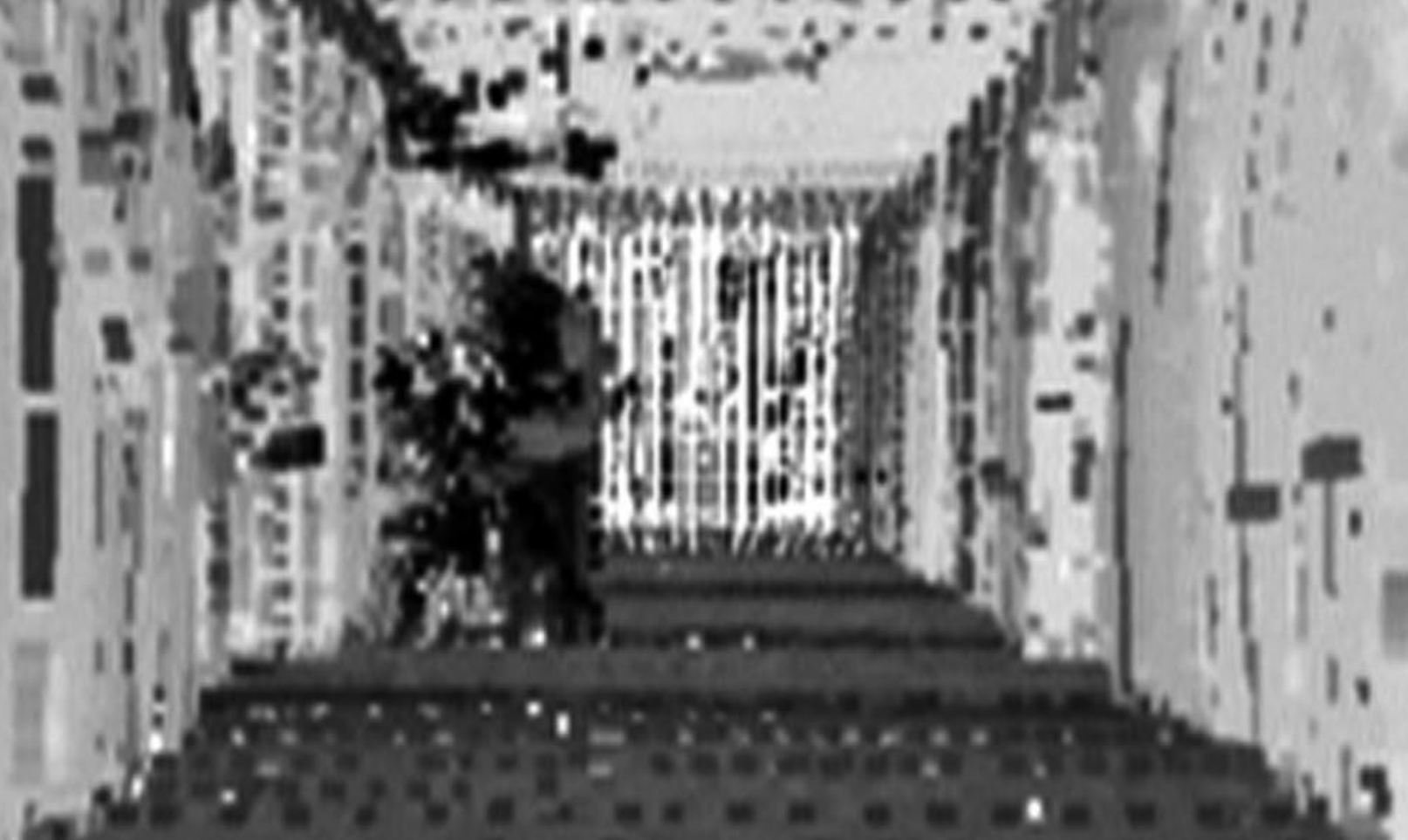

min

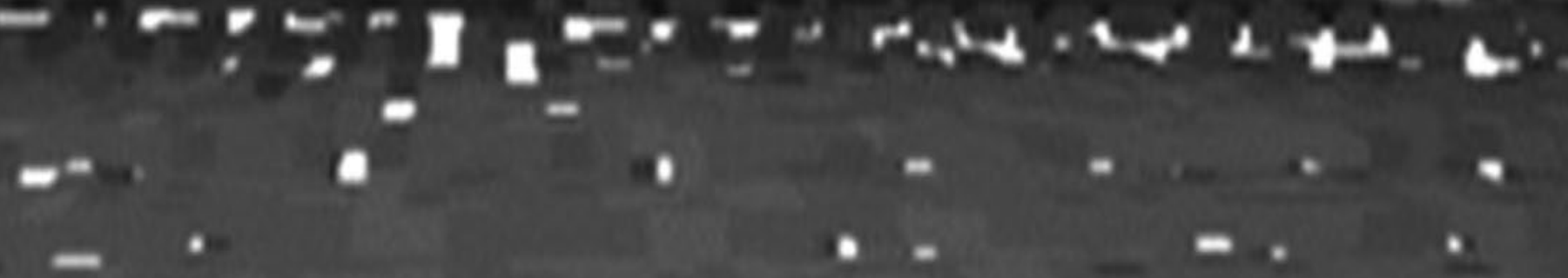

ISSN 2463-8501 $14 €_{18}^{12 \mathrm{~GB}} \mathrm{USD}$
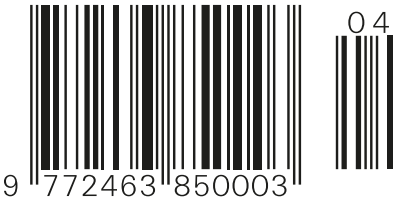